\title{
SUSTAINABLE DEVELOPMENT AND DEVELOPMENT POLICY BASED ON INNOVATION
}

\author{
HANNA PONDEL, ${ }^{1}$ IZABELA BLUDNIK ${ }^{2}$
}

${ }^{1}$ Poznan University of Economics and Business, POLAND

e-mail: hanna.pondel@ue.poznan.pl

${ }^{2}$ University of Szczecin, POLAND

e-mail: izabela.bludnik@wzieu.pl

RECEIVED

ACCEPTED

JEL

CLASSIFICATION

KEYWORDS

ABSTRACT
20 April 2018

12 July 2018

E12, Q56, Q58

sustainable development, development policy, environment, mainstream economics, heterodox economics, Post Keynesian Economics

The article presents the concept of sustainable development and attempts to evaluate the assumptions of the Polish development policy based on innovation in relation to this concept. It points out the need for a more thorough discussion on this subject and moving away from the adopted primacy of economic growth, typical of mainstream economics for a more comprehensive perspective, taking into account primarily the natural environment. The theoretical achievements of heterodox economics, especially Post Keynesian Economics, could be helpful in building such a comprehensive approach.

\section{Introduction}

The issue of sustainable development has been present in the literature for a long time. In recent years, however, the interest in it has significantly increased, especially in the case of one of the dimensions of sustainable development, namely the natural environment. The obvious reason for this is the increasingly voiced concern about the impending ecological disaster. More and more representatives of various schools and theoretical strands take 
up this subject, as one of the challenges every modern society has to face. This intellectual revival is especially noticeable within heterodox economics, which is hardly surprising when one takes into account its foundations: fundamental uncertainty, historical time, path dependency, lack of automatic market forces, or irreversibility of decisions. They constitute an excellent starting point for the analysis of the environment, ecology, resource depletion and the limits of growth. At the same time, deeper reflection on this subject is not to be found under mainstream economics, which - based on the neoclassical principles - still succumbs to a fetish of GDP growth, without noticing the resulting threats and limitations.

This intensification of research in the area of sustainable development and its environmental dimension, which may contribute to the evolution of a new approach - the economics of sustainable development, does not appear to have any major impact on the ongoing discussions on development policy in Poland. Although the documents presented by Prime Minister Morawiecki, i.e. the Responsible development plan (2016) and the Responsible development strategy 2020 (2017) do express the ambition to enter the path of economic development based on innovation, many of the relevant burning issues remain unnoticed or underestimated.

The aim of this article is to present the concept of sustainable development and to assess the assumptions adopted in Poland's development policy based on innovation in relation to this concept. In Poland, there is still a lack of a comprehensive approach to contemporary challenges, and in the planning of long-term development, a neoliberal approach (with emphasis on economic growth) is still more visible than the heterodox one (accentuating the environmental aspect, combined with economic and social aspects).

\section{The essence of sustainable development}

The beginnings of activities that fit into the concept of sustainable development date back to the $1960 \mathrm{~s}$ and the rise of awareness of environmental issues resulting from industrial revolutions or the demographic revolution started in the nineteenth century. The turning-points in the concept dissemination can be found in the attempt at formulating its principles during the international conference in Stockholm in 1972, concretizing the concept sustainable development during the Third Managing Session of the United Nations Environment Program (UNEP) in 1975, or forming its explicit definition in Brundtland Report entitled Our Common Future, published in 1987. In the said Report of the World Commission on Environment and Development (WCED) it was emphasized that Humanity has the ability to make development sustainable - to ensure that it meets the needs of the present without compromising the ability of future generations to meet their own needs (Report..., 1987, p. 24). Such a general definition of sustainable development influenced the universal acceptability of the concept and its use in various programs and documents in the years that followed.

With time, new proposals to define and understand sustainable development appeared; they emphasized more its economic, social and environmental dimensions, as well as the necessity of actions aimed at achieving the so-called integrated order. ${ }^{1}$

Despite the huge number of definitions, some elements recur in most of them: sustainable development is a type of socio-economic development, it includes both current and future generations, it integrates the activities of various entities, it must be considered in a multidimensional way. Munasinghe (2001) notes that there is no single

${ }^{1}$ Sources of information on sustainable development most often indicate three of its dimensions: economic, social and environmental, while some of them also include other dimensions: spatial, institutional or political, and institutional. 
discipline that can cope with the multiplicity of issues related to sustainable development and proposes sustainomics, resulting from the need to analyze various areas affecting the success of implementing this development concept.

The analysis of the changes that the concept of sustainable development has undergone over the years, allows distinguishing several turning points of particular importance for the formulation of the principles of this modern model of civilization development. The initial rules were the ones for eco-development - typically eco-development sets of rules can be found, for example, in the Stockholm Declaration, World conservation strategy from 1980, or World Charter for Nature from 1982. Rights and obligations in the area of stable and sustainable development were comprehensively specified in Rio Declaration (hereinafter The Earth Charter) and Action Program - Agenda 21 from 1992. Initially, sustainable development focused on the protection of the natural environment, currently - the quality of human life is in the centre of attention.

Contemporary development challenges, megatrends and changing conditions for the functioning of societies and economies lead to a continuous evolution of the goals of this development. In 2000, during the UN Millennium Summit, Millennium Development Goals were defined for the years 2000-2015. They covered such areas as hunger and poverty, education, equality, health, environment, living conditions, and development partnership. In September 2015, during the United Nations Sustainable Development Summit 2015, the Transforming our world: the 2030 Agenda for Sustainable Development was adopted, whose goals replaced the Millennium Development Goals. The new objectives are based on the conclusions from the analysis of the implementation of earlier objectives, in particular regarding the uneven progress in the implementation of actions between regions, countries, cities and rural areas, as well as deficiencies in many areas of socio-economic life. As opposed to the Millennium Goals, which were directed only to developing countries, the objectives of Agenda 2030 cover all countries. One example is the inclusion of sustainable production and consumption - a goal particularly important for highly developed countries (Central Statistical Office, 2016).

Despite years of discussion and interest in the concept expressed by various milieus, many of its aspects still remain unspecified, e.g. the definition of sustainable development, the translation of the term sustainable development into foreign languages, the approach to durability, the methodology of measurement to be adopted for this new development paradigm. The issue of whether sustainable development is an idea, a concept, or a theory is also disputable, also in scientific circles. Borys (2011, p. 76) indicates two approaches to the problem of concretizing the concept: the advocates of the first approach do not recognize sustainable development as a new paradigm, but rather a confused, non-specific, postulative, and unscientific concept (or in extreme cases - simply a scam); the representatives of the second approach recognize the concept as a well-described paradigm, a real alternative to pushing our civilization to barbaric positions, (...) of growing specificity at different levels of management, in various fields and disciplines. In the discipline of economics, linking the scientific base with the assumptions of the new paradigm is still difficult and open, although actions are being undertaken in this area. One example is the economics of sustainable development, that is an economic theory, based on transdisciplinary foundations, striving to determine the conditions of management, ensuring high economic, socio-cultural and ecological standards within the limits of environmental tolerance and consistent with the principle of intra-and intergenerational equity (Rogall, 2010). 


\section{Development policy based on innovation in Poland}

The plans of implementing in Poland a development policy based on innovation were reflected in two documents presented by Prime Minister Morawiecki, namely the Plan for responsible development (2016) and the Strategy for responsible development by 2020 (2017). None of them, however, satisfactorily takes into account the conclusions of the ongoing debates about the problem of sustainable development, its environmental aspect in particular.

In the first document, among the diagnosed five development traps, no one is related to the management of the natural environment, and one of the five pillars of development is sustainable social and regional development. Emphasis is placed on including both urban agglomerations and rural areas in development processes, eliminating discrepancies in the inhabitants' access to public services and the labor market, developing local markets, promoting entrepreneurship and multi-functionality of rural areas (Plan..., 2016, p. 3-8). Therefore, it can be concluded that the authors continue to yield to the pressure of the GDP growth, ignoring the problems of resource depletion, pollution, environmental degradation and accumulation of harmful waste.

A similar impression can be gathered in the case of the Strategy... (2017) - in many areas, insufficient emphasis is placed on the natural environment, both as a stimulator and beneficiary of development processes. Admittedly, responsible development has been defined as socio-economic development that integrates political, economic and social activities, while maintaining the natural balance (Strategy..., 2017, p. 35), but the natural environment (especially its improvement) is treated only superficially. An analysis of the document reveals that the individual dimensions of sustainable development are not treated equally, and such issues as entrepreneurship, income growth, reindustrialization, innovation or economic growth obscure environmental issues accompanying the implementation of projects in these areas.

It seems that at least in the main purpose of the Strategy, which is creating conditions for the growth of income of Polish citizens, while simultaneously increasing the cohesion in the social, economic, environmental and territorial dimension (Strategy..., 2017, p. 49), an emphasis should definitely be placed on the improvement of the natural environment. Income growth is important for improving the quality of life, but it is no less crucial to improve the living conditions, including the condition of the natural environment in which people live.

The insufficient emphasis on ecological issues in the Strategy was indicated by many institutions, associations, and entities participating in social consultations accompanying the preparation of the final version of the document (including the Institute for Renewable Energy, Foundation for Sustainable Energy, National Council of Agricultural Chambers, National Chamber of Commerce). The comments concerned, for example, the issue of greenhouse gas emissions or energy - an area that the specialists from the Institute of Renewable Energy (IEO, 2016) evaluated as one of the weakest parts of the Strategy. The arguments that Energy - one of the five "impact areas" listed in the Strategy, does not meet expectations include: 1) not supporting the objective of sustainable economic growth of the country and not serving territorially balanced development, 2) proposing innovations in the energy sector whose implementation is dubious, 3) excessive costs of some of the proposed actions. What was recognized as especially dangerous is inhibiting the development of dispersed renewable energy sources in favor of the excessive concentration of actions aimed at developing coal and nuclear power solutions (IEO, 2016). 


\section{Conclusions}

The assumptions of the development policy based on innovation in Poland, presented in the Plan... (2016) and the Strategy... (2017), clearly underestimate various aspects of sustainable development, especially environmental and ecological issues. Given the importance of these issues in the majority of highly developed countries around the world, it will be difficult to avoid discussing them. It is certainly worth learning from both the achievements and errors of economics, conducting their critical analysis from the point of view of contemporary (and previously non-existent) determinants of development, the variability of the environment and the current conditions of human functioning.

The proposals contained in both documents fit into the perspective of mainstream economics, which is strongly criticized for pushing the primacy of GDP growth, ignoring its disastrous effects on the environment, and thus the quality of life and social well-being. In order to deepen the discussion on sustainable development, it would be much more conducive to reach for the achievements of other paradigms, schools or theoretical strands. The most obvious choice seems to be the economics of sustainable development (Rogall, 2010) or Ecological Economics (Daly, 1990, 1996; Söderbaum, 2000; Røpke, 2005). However, the former is only just being formed, while the latter clearly lacks solid macroeconomic foundations.

Theoretically advanced macroeconomic models integrating such issues as the limits of economic growth, the state of the ecosystem and even financial instability can be found in Post Keynesian Economics, which in recent years has produced a rich literature, attempting to combine Post Keynesian macroeconomics with the perspective of Ecological Economics, and especially with the issues of sustainable development (Holt, Pressman, Spash, 2009; Kronenberg, 2010; Spash, Ryan, 2012; Fontana, Sawyer, 2013, 2016; Rezai, Taylor, Mechler, 2013; Taylor, Rezai, Foley, 2016).

There is no doubt that both the diagnosis of the current socio-economic condition in Poland and the implementational aspect of the proposed development policy are not treated in a comprehensive and exhaustive manner in the said official documents. Therefore, it seems necessary to use macroeconomic models, which are certain to enable better efficiency of planning and implementation of various solutions within the framework of the country's development policy.

\section{References}

Borys, T. (2011). Sustainable Development - How to Recognize Integrated Order. Problemy ekorozwoju, 6 (2), 75-81 (in Polish).

Daly, H.E. (1990). Steady-State Economics: The Political Economy of Bio-Physical Equilibrium and Moral Growth. San Francisco: W.H. Freeman.

Daly, H.E. (1996). Beyond Growth: The Economics of Sustainable Development. Boston: Beacon Press.

Fontana, G., Sawyer, M. (2013). Post-Keynesian and Kaleckian thoughts on ecological macroeconomics. European Journal of Economics and Economic Policies, 10 (2), 256-267.

Fontana, G., Sawyer, M. (2016). Towards post-Keynesian ecological macroeconomics. Ecological Economics, 121, $186-195$.

GUS (2016), On the path towards sustainable development, Statistics Poland, Warsaw. Retrieved from: http://stat.gov.pl/obszarytematyczne/inne-opracowania/inne-opracowania-zbiorcze/na-sciezce-zrownowazonego-rozwoju,23,1.html (in Polish).

Holt, R., Pressman, S., Spash, C.L. (eds.) (2009). Post Keynesian and Ecological Economics: Confronting Environmental Issues. Cheltenham: Edward Elgar.

IEO (2016), Energy - the weakest link in the Strategy for Responsible Development? Retrieved from: http://ieo.pl/pl/aktualnosci/1114energetyka-najslabsze-ogniwo-strategii-na-rzecz-odpowiedzialnego-rozwoju (in Polish). 
Kronenberg, T. (2010). Finding common ground between ecological economics and post-Keynesian economics. Ecological Economics, 69 (7), 1488-1494.

Munasinghe, M. (ed.) (2001). The sustainability of Long-term Growth. Socioeconomic and Ecological Perspectives. CheltenhamNorthampton: Edward Elgar Publishing.

Plan for responsible development (2016). Annex to the resolution of the Council of Ministers no 14/2016 of 16 February 2016. Retrieved from: http://www.miir.gov.pl/media/16403/uchwala_plan_odp_rozw_16022016.pdf (in Polish).

Report of the World Commission on Environment and Development (1987). Note by the Secretary-General, United Nations, General Assembly, 4 August 1987. Retrieved from: https://sustainabledevelopment.un.org/milestones/wced.

Rezai, A., Taylor, L., Mechler, R. (2013). Ecological macroeconomics: an application to climate change. Ecological Economics, 85, $69-76$.

Rogall, H. (2010). Economics of sustainable development. Theory and practice. Poznan: Zysk i S-ka Publishing House (in Polish).

Røpke, I. (2005). Trends in the Development of Ecological Economics from the late 1980s to the Early 2000s. Ecological Economics, 55 (2), 262-290.

Söderbaum, P. (2000). Ecological Economics. London: Earthscan.

Spash, C.L., Ryan, A. (2012). Economic schools of thought on the environment: investigating unity and division. Cambridge Journal of Economics, 36 (5), 1091-1121.

Strategy for responsible development by 2020 (with a perspective by 2030) (2017). Resolution of the Council of Ministers no. 8 of 14 February 2017. Retrieved from: http://prawo.sejm.gov.pl/isap.nsf/download.xsp/WMP20170000260/0/M20170260.pdf (in Polish).

Taylor, L., Rezai, A., Foley, D. (2016). An integrated approach to climate change, income distribution, employment, and economic growth. Ecological Economics, 121, 196-205.

Cite this article aS: Pondel, H., Bludnik, I. (2018). Sustainable development and development policy based on innovation. European Journal of Service Management, 3 (27/1), 205-210. DOI: 10.18276/ejsm.2018.27/1-25. 